\title{
How to Analyze the Potential of Digital Games for Human Rights Education
}

\author{
Sonja Gabriel
}

\begin{abstract}
:
Serious games that address topics related to human rights education have become increasingly available since the launch of Escape from Woomera in 2003, a game that raises awareness of the plight of refugees. A majority of serious games in the field of human rights focus on topics related to refugees and poverty in order to raise awareness and evoke empathy for the groups depicted. The paper introduces the Serious Games Design Assessment (SGDA) Framework as a tool to find out if a certain game might be used to achieve the objective the designer intended when designing the game. Using the game Bury Me, My Love, which shows the journey of a Syrian woman wanting to escape to Europe, the approach is explained in detail. The conclusion of the game-analysis shows that Bury Me, My Love can be regarded as a successful example of a serious game that introduces and engages the player in what it means to leave your home country as all game-design elements support the purpose.
\end{abstract}

\section{Keywords:}

human rights; games for change; serious games; game-design; teaching. 


\section{Como analisar o potencial dos jogos digitais para a educação em direitos humanos}

Resumo: Os jogos sérios que abordam tópicos relacionados com a educação em direitos humanos têm-se tornado cada vez mais disponíveis desde o lançamento do Escape from Woomera em 2003, um jogo que conscientiza a situação dos refugiados. A maioria dos jogos sérios no campo dos direitos humanos concentra-se em tópicos relacionados com refugiados e pobreza, a fim de aumentar a conscientização e evocar empatia pelos grupos representados. O estudo apresenta a Estrutura do Serious Games Design Assessment (SGDA) como uma ferramenta para avaliar se um determinado jogo pode ser usado para atingir o objetivo que o designer pretendia ao criar o jogo. Usando o jogo Bury Me, My Love, que mostra a jornada de uma mulher síria que deseja fugir para a Europa, a abordagem é explicada em detalhes. A conclusão da análise do jogo mostra que Bury Me, My Love pode ser considerado como um exemplo bem sucedido de um jogo sério que introduz e envolve o jogador no que significa deixar o seu país de origem, pois todos os elementos de design do jogo apoiam o objetivo.

Palavras-chave: direitos humanos; jogos para mudança; jogos sérios; design de jogo; ensino.

\section{Comment analyser le potentiel des jeux numériques pour l'éducation aux droits de l'homme}

Résumé: Les jeux sérieux qui traitent de sujets liés à l'éducation aux droits de l'homme sont devenus de plus en plus disponibles depuis le lancement de Escape from Woomera en 2003, un jeu qui sensibilise à la détresse des réfugiés. Une majorité de jeux sérieux dans le domaine des droits de l'homme se concentrent sur des sujets liés aux réfugiés et à la pauvreté afin de sensibiliser et d'évoquer l'empathie pour les groupes représentés. L'article présente le cadre SGDA (Serious Games Design Assessment) comme un outil permettant de déterminer si un jeu donné peut être utilisé pour atteindre l'objectif que le concepteur avait prévu lors de la conception du jeu. En utilisant le jeu Bury Me, My Love, qui montre le voyage d'une Syrienne qui veut fuir en Europe, l'approche est expliquée en détail. La conclusion de l'analyse du jeu montre que Bury Me, My Love peut être considéré comme un exemple réussi de jeu sérieux qui introduit et engage le joueur dans ce que signifie quitter son pays d'origine puisque tous les éléments de game design supportent le but.

Mots clés: droits de l'homme; des jeux pour le changement; jeux sérieux; le design du jeu; enseignement.

\section{Cómo analizar el potencial de los juegos digitales para la educación en derechos humanos}

Resumen: Los juegos serios que abordan temas relacionados con la educación en derechos humanos se han vuelto cada vez más disponibles desde el lanzamiento de Escape from Woomera en 2003, un juego que aumenta la conciencia sobre la difícil situación de los refugiados. La mayoría de los juegos serios en el campo de los derechos humanos se centran en temas relacionados con los refugiados y la pobreza con el fin de crear conciencia y evocar empatía por los grupos representados. El documento presenta el Marco de evaluación de diseño de juegos serios (SGDA, por sus siglas en inglés) como una herramienta para descubrir si un cierto juego se puede usar para lograr el objetivo que el diseñador pretendía al diseñar el juego. Usando el juego Bury Me, My Love, que muestra el viaje de una mujer siria que quiere escapar a Europa, el enfoque se explica en detalle. La conclusión del análisis del juego muestra que Bury Me, My Love puede considerarse como un ejemplo exitoso de un juego serio que introduce e involucra al jugador en lo que significa abandonar su país de origen, ya que todos los elementos de diseño del juego respaldan el objetivo.

Palabras clave: derechos humanos; juegos para el cambio; juegos serios; Diseño de juego; enseñando. 


\section{Introduction}

The right to education is one of the central human rights and it also includes the right to learn about human rights. As stated by the 'OHCHR | Human Rights Education and Training' (n.d.), this is especially important as "values, beliefs and attitudes that encourage all individuals to uphold their own rights and that of others" are conveyed by human rights education and thus can help to create a just society as well as prevent human rights violations. The World Programme for Human Rights Education which started in 2005 is currently in its third phase which builds on its first two phases that support the development of knowledge and skills, as well as attitudes and behaviors that support international human rights (United Nations, 2014). The number of serious games dealing with human rights topic has been on the rise for the last years. However, there has not been much research in how far these games might change people's attitudes and if that's possible which game-design elements help the games to succeed.

Games for Change is a non-profit organization which promotes games with positive social purposes beyond play (Klopfer, Osterweil, \& Salen, 2009). The mission of the organization corresponds with the aims of human rights education, which are often divided into learning about, by and for human rights. Learning about human rights includes knowing about facts and resources like basic documents and organizations, as well as understanding the difference between rights, duties and knowing about (further) development of human rights. Learning by human rights refers to attitudes, values and making judgements like reflecting, recognizing manipulation, developing empathy or criticizing human rights violations. Finally, learning for human rights refers to decision-making and responsibility, empowerment and acting within the context of human rights for social justice.

\section{A Brief History of Digital Human Right Games}

Escape from Woomera (2003) is one of the early attempts to focus on human rights in a digital game. The game puts players in the role of an Iranian asylum seeker whose request for asylum has been denied and who therefore decides to plan his escape from Woomera. The game design restricts choices for the players so that they take on the role of the game character - being restricted and frustrated because of the limited choices and possibilities for where to go and what to do. Poremba (2013: 359) points out: "Woomera succeeds less by immersing players in a physical space or revealing truths about the logic of Woomera and detainee strategy, and more in crafting insight into the enacted subjectivity of Woomera refugees, read through the player's embodied gameplay experience." Although using game-mechanics of a typical adventure game Escape from Woomera was criticised as being too didactic as it imposes the designer's opinion of 
what to think about life as a refugee in Australia (Golding, 2013). There are hundreds of digital serious games which focus on topics like poverty, discriminations, refugees, gender issues, or child labor. The majority of these games have been supported or funded by non-governmental organizations (NGOs) and can be categorized according to their aims: (1) to raise awareness about specific problems or human right violations, (2) to criticize certain situations and (3) to motivate action related to these topics on the part of players. Like commercial games, these digital games use a variety of game-design strategies to deal with human rights. Some of the games are not oriented towards any particularly fun experiences. This might cause players to quit the game without ever turning to it again. Green (2014: 39) writes that "these types of games have earned the pejorative nickname 'chocolate covered broccoli' in that they are little more than basic and boring drills dressed up in a thin video game shell." Fun, therefore, has to be regarded as a key-element of even serious games. However, one has to bear in mind that fun can be seen in different ways (Lazzaro, 2015). Serious fun, for example, refers to purposeful play in which players would like to make a difference in their real world. Making a serious game fun to play can be difficult for designers as "increasing system realism allows you to communicate a deeper message but typically makes for a less accessible, less fun play experience and thus less people will want to play the game" (Swain, 2007, p. 808). Apart from fun, other important factors in games include being very emotional or games using the concept of satire. Video-games can also be regarded as useful tools for fundraising and creating awareness (Stokes, Seggerman, \& Rejeski, 2011).

Most games found with topics related to human rights aim to highlight human rights violations by putting the player in the shoes of a character whose rights are violated or by having the player take on the role of a helper. Topics of these serious games range from situations of refugees from different countries, politics over poverty and child labour and exploitation to equal opportunities. Although the games often deal with similar topics as they try to teach players various aspects of human rights, there are notable differences in the game design elements, i.e. narration, game mechanics used (especially rewards used within the games), aesthetics or facts and information presented.

Ayiti - The Cost of Life (Global Kids \& Game Lab, 2006) was designed with the help of high school students to teach primary school children in industrialized countries the relationship between poverty and education. The simulation presents the player with the Guinnard family (parents and two children) who live in rural Haiti. The game principles are quite easy - the player has to decide who is going to work, who is allowed to attend school, and who should stay at home (and work at the family farm). Players can check on family members' conditions including wellbeing, happiness, and education. Winning the game means that the family has to survive for 4 years (16 seasons). The game challenges typical Western beliefs as sending all children to school ends the family in poverty, sickness, and death (Ferri \& Fusaroli, 2009, p. 36). This way the game 
mechanics show the complex interaction between the need for education in order to get a better pay and a less dangerous job, but at the same time show that education in these countries is quite expensive. This means working hard (and risking one's health) is sometimes necessary. This vicious circle cannot be broken by simply telling people in less developed countries to send their children to school. What is quite remarkable about the game is that it comes with a lesson plan giving implementation suggestions for school use as well as background information about Haiti and the human right to education. The game is still used by many teachers around the world to teach about poverty in less developed countries.

Another game dealing with less developed countries is Darfur is Dying (Take Action Games, 2006) - a browser-based game about the crisis in Darfur. The game won the Darfur Digital Activist Contest sponsored by mtvU. It consists of two modes. In the first part, players choose a family member and are sent to forage for water. If the character is captured by a patrol of the Janjaweed militia, the player receives information of what would probably have happened to their character and is asked to select another family member. In the second mode, a refugee camp needs to be managed - the character has to use the water collected before for growing crops and has to build huts. When water runs out, the player returns to the first mode. In less than half a year after having been published, the game had been played by more than 800,000 people (Parkin, 2006).

After the successful creation of games which aimed at making people aware of social problems, game designers (and the organizations financing them) also came up with the idea of using games as a means of fund-raising. Free Rice (United Nations World Food Programme [UNWFP], 2007) is a website that provides game-like challenges by providing multiple-choice quizzes for different subject areas (e.g., English, mathematics, foreign languages, geography). For every question the user answers correctly, 10 grains of rice are donated via the World Food Programme. In 2007 more than 12 billion rice grains were donated ('Totals | Freerice.com', 2015). As the website is constantly being updated, it still attracts many users. In the first 10 days of July 2015, nearly 60 million grains were collected by visitors who answered the questions. Players can sign up and keep track of their collected amounts of rice, as well as create and join groups. Meanwhile, there are more games working according to the "feel good" motto while playing and donating to charities (Basu, 2010). There are games that even go one step further. Half the Sky Movement: The Game (Frima Studio, 2013) was co-produced by Zynga and the Games for Change movement as part of a transmedia project. The game is about the empowerment of women around the world and addresses various problems women have to face in society. The player starts out in India playing Radhika, who must decide if she should confront her husband about the necessity of getting medicine for their sick daughter. Decisions taken by the player that empower women are rewarded by the game. This game - as usual for games in social networks - encourages 
players to invite friends to play as well, because sometimes support from other players is needed to complete a quest. To be able to play mini-games or travel within the game you need energy - which you can wait to be filled up after some time or you can buy energy using real money. Most of the money earned by in-app purchases is donated to charities. Additionally, there are some more incentives for players to come back and play the game. For example, when reaching a certain amount of points, books or medicine are donated, giving players the good feeling of being able to help by playing the game regularly. The launch of the game generated a huge media discussion, as the plot follows a book and a film dealing with the same topic (Holpuch, 2013; Wolonick, 2013). The game can be regarded as successful as measured by the number of players and donations. By June 2015 the game had 1.3 million players, reported 250,000 book donations, and generated a total of more than US $\$ 500,000$ in overall donations ('Half The Sky Movement Game', 2015).

Apart from using social networks, recent games also make use of the latest hardware developments. Outcasted (Köln International School of Design, 2014) is a stand-alone first-person-simulation making use of Google's Oculus Rift to enable a completely new game experience. Players take the role of a homeless person living on the streets of a western city. The player's task is to draw passing pedestrians' attention to the playable character in order to receive money. The only action players can carry out is moving their heads to try and elicit eye-contact. Some of the passersby will start talking. Some will even give the character money. Still, more of them will ignore, insult, or even get aggressive towards the character. The developers of Outcasted intend to make people feel what it is like to depend on another people's goodwill.

As values can be integrated into digital games in various ways (cf. Flanagan \& Nissenbaum, 2014), these games differ in great extent from each other regarding game design and narratives, as well as how the topics and contents are realized (cf. Gabriel, 2016). The following sections will introduce the research carried out regarding games dealing with human right topics and show how the SGDA Framework can be used to find out if the game might support teaching about human rights.

\section{Methodology}

To find out about the potential of serious games, it is necessary to have a closer look at the underlying game design. For this research the Serious Game Design Assessment Framework (SGDA Framework) by Mitgutsch \& Alvarado (2012) was used. This approach analyzes "a game's formal conceptual design, its elements, and their relation to each other based on the game's purpose" (ibid p. 121) and therefore helps to assess its possible impact. The SGDA Framework consists of six core components and puts purpose in the center of them all as this should be reflected in all other elements. The 
other five components are content, fiction and narrative, mechanics, aesthetics and graphics and finally, framing. The SGDA Framework was chosen as it puts emphasis on purpose when evaluating serious games which matches the objectives of human rights education. As Mitgutsch \& Alvarado (2012: 123) state, purpose is not only reflected in the objectives and topic of the game but also in the designer's intentions as the latter wants to achieve an impact beyond game-play. The game-design influences if there might be a possible transfer of empathy or change of behavior from the game into reality.

Before some of the games were analyzed according to the SGDA Framework, a quantitative online content analysis was carried out to identify those serious games that deal with topics of human rights (violations). Using the search-engine Google different keywords ("serious game", "human rights", "digital game", "immigration", "refugee", "poverty", "human rights violation" "migration" "child labour", "war", "homeless", "conflict" and "disaster") were used in different combinations and in the languages of German and English to find as many games as possible. Each search result was analyzed if it is a serious game that addresses one of the human rights. Only those games were included in the list whose purpose could explicitly identified as wanting to convey a message focused on human rights (e.g. discrimination against certain groups, freedom of thought, right to education or rights for asylum seekers). Serious games that deal with human rights as a second theme were not included in the list.

\section{Results of Quantitative Online Content Analysis}

The research resulted in a list of serious games on various human rights topics. As can be seen in Table 1, an emphasis on certain topics can be found. The most prominent topic is poverty with a focus on poverty in developing countries that introduces players to what it means if there is not enough food, housing and other available resources due to (civil) war or natural disasters. Another subgroup of the poverty theme deals with factors that might lead to poverty in the so-called rich countries. For example, these games might introduce players to people who do not earn enough money to pay the costs of daily life. Finally, a third sub-group of the poverty theme in games features homeless people in European or US-American countries by illustrating the challenges and obstacles these people have to overcome in their daily struggle to survive.

Many games also deal with topics around refugees, asylum seekers and migration especially those which were published since 2013 due to the topic being present in media and also affecting many people's lives. These games partly deal with legal migration to another country and the game characters facing various challenges to get settled in their new surroundings. A second group of games in this category features people having been forced to leave their home countries and their risky journey into safety. 
Generally, most of the games listed aim at creating empathy for the depicted groups by putting players in the shoes of asylum seekers, refugees, poor or homeless people. However, some of them use a more humorous way to make people aware of the topic (as for example Smuggle Truck or Penner Game).

Table 1. Overview of serious games dealing with human rights

\begin{tabular}{|c|c|}
\hline TITLE OF THE GAME & TOPIC \\
\hline 3rd World Farmer & Poverty (developing country) \\
\hline A Breathtaking Journey & Refugees \\
\hline A Closed World & LGBT \\
\hline Against All Odds & Refugees \\
\hline Antiwargame & Terrorism \\
\hline Ayiti - The Cost of Life & Poverty (developing country) \\
\hline Bad Paper - The Debtor Game & Poverty (Western world) \\
\hline Bury Me, My Love & Refugees \\
\hline Cartlife & Poverty (Western world) \\
\hline Coming Out Simulator & LGBT \\
\hline Cool School: Were Peace Rules! & Conflicts \\
\hline Darfur is Dying & Refugees \\
\hline Das kostet die Welt & Landgrabbing \\
\hline Durch die Wild Web Woods & Basics of human rights \\
\hline Eliminate Child Labour & Child labour \\
\hline Endgame Syria & Conflicts \\
\hline Escape from Woomera & Refugees \\
\hline Execution & Death penalty \\
\hline Finding Home & Refugees \\
\hline Food Force & Hunger \\
\hline FreeRice & Poverty \\
\hline Frontiers & Refugees \\
\hline Garbage Dreams & Poverty (developing countries) \\
\hline GetH2O & Water shortage \\
\hline Global Conflicts Palestine & Conflicts \\
\hline Go Goat Go & Poverty (developing countries) \\
\hline Half the Sky & Gender discrimination \\
\hline Hobson's Choice & Poverty, homeless people \\
\hline Home Behind & Refugees, civil war, \\
\hline Homeland Guantanamos & Refugees \\
\hline
\end{tabular}




\begin{tabular}{|c|c|}
\hline TITLE OF THE GAME & TOPIC \\
\hline Hush & Conflicts \\
\hline ICED - I Can End Deportation & Refugees \\
\hline Inside the Haiti Earthquake & Natural disasters \\
\hline Layoff & Discrimination \\
\hline Lim & Violence \\
\hline Live58 & Developing countries \\
\hline Mainichi & Transgender \\
\hline Maria Sister's: Clean Room & Immigration \\
\hline Marketplace Poverty Simulator & Poverty (Western world) \\
\hline Mars Generation One: Argubot Academy & Ethical decision taking \\
\hline Mission & Poverty, homeless people \\
\hline Mission 4: City of Immigrants & Immigration \\
\hline No Game! & Poverty \\
\hline On the Ground Reporter: Darfur & Conflicts \\
\hline One Hen & Developing countries \\
\hline Outcasted & Poverty, homeless people \\
\hline Papers, Please & Totalitarian regime \\
\hline Parable of the Polygons & (Ethical) decision taking \\
\hline Parable oft he Polygons & Ethical decision taking \\
\hline Peacemaker & Conflicts \\
\hline Penner Game & Poverty, homeless people \\
\hline Penner Game 2 \% & Poverty, homeless people \\
\hline People Power - The Game of Civil Resistance & Civil rights \\
\hline Phone Story & Exploitation \\
\hline PING - Poverty is not a Game & Poverty (Western world) \\
\hline Quandary & Ethical decision taking \\
\hline Refugee & Refugees \\
\hline September 12th: A Toy World & Terrorism \\
\hline Sim Sweatshop & Exploitation, Child Labour \\
\hline Smuggle Truck & Refugees \\
\hline Spent & Poverty (Western world) \\
\hline Survival & Refugees \\
\hline Sweatshop & Exploitation, child labour \\
\hline Syrian Journey & Conflicts \\
\hline The Invisible Hand & Fair trade \\
\hline
\end{tabular}




\begin{tabular}{|l|l|}
\hline \multicolumn{1}{|c|}{ TITLE OF THE GAME } & \multicolumn{1}{c|}{ TOPIC } \\
\hline The Migrant Trail & Refugees \\
\hline The Unfair Factory & Exploitation \\
\hline This War of Mine & War \\
\hline Ulitsa Dimitrova & Poverty, homeless people \\
\hline Unstoppables & Discrimination \\
\hline Wildfire & Poverty, gender discrimination, education \\
\hline
\end{tabular}

Source: Authors.

Games were chosen for analysis with the Serious Games Design Assessment Framework based on either their publication in 2016 or 2017 , or according to their popularity, as determined by the frequency of references in newspaper articles or research papers. The following analysis of Bury Me, My Love, published in 2017 and mentioned in many articles, is an example of a game that represents both criteria.

\section{Analysis of Bury Me, My Love}

Bury Me, My Love (Playdius 2017) is a smartphone app for iOS and Android that tells the story of a young woman called Nour who flees Syria and attempts to reach Europe in safety. The app is an interactive story told via a communication tool similar to WhatsApp. The player takes on the role of Majd who stays behind and can only occasionally text with his wife, send/receive photographs or emojis while she is on her dangerous journey. So, the player can provide Nour only with advice and support being able to influence her decisions and moves to a certain extent. Florent Maurin (2017:1), the designer of Bury Me, My Love, calls the game "a reality-inspired game, a fiction directly derived from real events [...]". It is based on an article Maurin read in 2016 and on the actual experiences by a refugee from Syria who went on basically the same journey Nour has to undertake within the game. The title refers to an Arabic farewell meaning "Take care".

\section{Purpose}

The topic of the game is to show players the reasons why people leave Syria and which hardships they have to endure when these people try to flee to a safe country. The designers of the game state their purpose as following:

"Our two main characters, Nour and Majd, are fictional. They do not exist, or rather, they exist collectively. They are a multitude of men, women and children: Dana, her mother, her brother-in-law... as well as thousands of others who flee their country - or watch their relatives flee - all in hopes 
of finding a better life in Europe. This story is about those who achieve that goal. It is about those who don't. It is about those who die trying. It is about the world around us. Something which we hope will lead you to keep pondering on after it is over." ('Bury me, my Love - A Story of Love, Hope and Migration', n.d.)

The game provides 19 different endings, thus ensuring that the decisions taken by the players really matter as the game takes different turns depending on the options chosen. Only one ending results in escape whereas the other 18 either end in death or imprisonment of Nour.

\section{Content and Information}

As the game relies on accounts by someone having fled from Syria, the information presented within the game is realistic and evidence-based. Bury Me, My Love is mostly based on text, which means there are many data and facts used. The information is presented along the way, integrated in the story and relies on facts as well as personal experience by people interviewed for the game. However, to make the conversation between Nour and Majd more natural and realistic, prejudices and judgmental expressions are used as well. Apart from the text, the game provides a map from which the player can see the places Nour has already traveled to as well as some information about the historical or geographical importance of the place and relevant information regarding Syrian refugees. For example, when clicking on Beirut within the map, you get the following information: "As of March 2016, there were over 305000 Syrian refugees officially registered in Beirut. They accounted for $16 \%$ of the city's population." The app tracks the progress and the journey using the map as a diary and thus changes from game to game, depending on the decisions taken by the player.

\section{Game Mechanics}

As per Sicart (2008: 6) game mechanics is defined "as methods invoked by agents, designed for interaction with the game state" which subsumes the establishment of the rules but also the in-game goal of the game, the operation of the reward system, obstacles/challenges within the game, the difficulty balancing and the win conditions" (Mitgutsch \& Alvarado, 2012). The goal in Bury Me, My Love is to make decisions which enable the non-playable character Nour to arrive Europe safely. The players can only choose between a limited choice of answers or dialogue-parts, sometimes even choose between two different emoticons to send and thus cannot foresee how the decision will influence the story (or if Nour will even follow the piece of advice given by the player). The only feedback the player gets is the advancement Nour makes or the difficulties she has to face as a result of the decisions taken. There are no points or 
badges awarded, no levels. Advancement can only be seen from the map. However, there are some variables which will influence Nour's decisions and actions: her morale, her relationship level with Majd, her budget and the presence or absence of specific objects in her inventory.

\section{Fiction and Narrative}

The fictional context and the fictional world created is crucial for Bury Me, My Love. The whole story unfolds right from the beginning just by conversations between Nour and her husband. As the game advances, the player learns more and more about the circumstances and reasons why only Nour sets out on the dangerous journey and what the couple experienced in their past. The player takes on the role of the husband, staying behind with his mother in a war-torn country, being unable to help his wife on the journey apart from giving support and advice. The game also enables players to choose the game's speed. If the "pseudo-real time" mode is switched on, the player needs to wait for the story to progress when Nour either does not have any network connection or needs to do something else. The game screen says, "Nour is busy." When she needs to talk to the player, a notification is sent. As the player takes on the role of Majd, it helps perspective-taking which "is the active consideration of an outgroup member's mental state, points of view, and motivation" (Darvasi, 2016: 7).

\section{Aesthetics and Graphics}

These elements refer to the audiovisual language of the game and thus "define the overall formal aspects that frame the content (information), the fiction (the world and characters of the game), the framing (target group), the setting, and the mechanics (instructions, rewards)" (Mitgutsch \& Alvarado, 2012: 126) The game uses a cartoonish style for depicting the characters (photographs and selfies sent in the game or the profile picture of Nour). The main game screen looks like a typical smartphone messenger app, showing Nour's messages in white font on a brown background and Majd's texts in black font on a white background. All conversations can be read up any time in the game. On the start of each day within the game, the date (day and month) is given. Sounds used are also similar to those of a smartphone messenger app. The map used to show important points in Nour's journey is similar to maps found on the internet (f.ex. Google maps). Although the characters are depicted with drawings, these are so detailed and natural, so that players get a feeling who Nour is. Aesthetics and graphics match the story and the framing without any contradiction.

\section{Framing}

The last aspect of the SGDA Framework deals with the framing of all the aforementioned elements in relation to the target group, as well as their play literacy and the 
broader topic of the game. The game does not address a specific target group since anyone interested in the game's topic should be able to play it. The game controls and the user interface are easy to use - there is not much the player can do anyway. Most of the time the player's task is reduced to reading, as not all of Majd's messages can be influenced. So, players need to be able to read quite well in order to follow the unfolding story. The topic of the story - Syrian refugees and their dangerous journey to Europe - is addressed in an emotional way and relies on the player's bonding with Nour and wishing for her to arrive safely in Germany (which is the target destination). There are no additional educational resources provided - indicating that the game was not directly meant to be used in classrooms. As the app provides 19 different endings and a lot of different conversations, depending on the choices taken before, there is a high degree of replayability.

\section{Conclusion}

As stated in the SGDA Framework, the game's purpose needs to be reflected in the individual elements to present a coherent and cohesive game system. When analyzing the relation between the game's content, its fictional context and the mechanics, the following can be stated: The purpose of the game is to show players which obstacles and dangers Syrian refugees have to overcome in order to live a life in safety. The play wants to create understanding and empathy by showing how difficult this goal is to achieve. By telling about the lives of refugees and those left behind in a very personal way, the game succeeds in providing information and evidence, without leaving the narrative structure. The game's disadvantage of leaving the players in a passive role without allowing them many choices (as only pre-formulated answers can be chosen from time to time) is at the same time mirrored by the actual impossibility of influencing a beloved person's fate because of the tenuous connection to a a smartphone. Thus, the game shows how important this device becomes for refugees as it is often the only connection to their family and friends. Of course, the impact of the game to evoke empathy with the players, cannot be answered by simply analyzing the game elements. However, this analysis shows that a game like Bury Me, My Love has a great potential to influence players and address the objectives of human rights education in the before-mentioned category of learning by human rights.

As shown in this paper, many serious games address topics that cover human rights education. Many of them like the example of Bury Me, My Love discussed, try to evoke empathy with the player. Not all these games reach this aim. This is specially the case when the purpose of the game is not reflected in the other elements as stated in the SGDA Framework. However, to make sure that players really learn something from the game, guided reflection and discussion of the game content might be needed additionally. 


\section{References}

Basu, S. (2010). 5 Cool Edutainment Games You Can Play and Also Donate To Charitable Causes. Retrieved 10 July 2015, from http://www.makeuseof.com/tag/5-cool-edutainment-games-playdonate-charitable/

Bury me, my Love - A Story of Love, Hope and Migration. (n.d.). Retrieved 9 February 2018, from http:// burymemylove.arte.tv/

Darvasi, P. (2016). Empathy, Perspective and Complicity: How Digital Games can Support Peace Education and Conflict Resolution. Mahatmi Gandhi Institute of Education for Peace and Sustainable Development / UNESCO. Retrieved from http://mgiep.unesco.org/wp-content/uploads/2016/12/ WORKING-PAPER-PAUL-DARVASI-.pdf

Ferri, G., \& Fusaroli, R. (2009). Which Narrations for Persuasive Technologies? Habits and Procedures in Ayiti: The Cost of Life. Retrieved 6 July 2015, from http://www.aaai.org/Papers/Symposia/ Spring/2009/SS-09-06/SS09-06-007.pdf

Flanagan, M., \& Nissenbaum, H. (2014). Values at Play in Digital Games (1st ed.). Cambridge, MA: The MIT Press.

Gabriel, S. (2016). Serious Games Teaching Values: Discussing Games Dealing with Human Rights Issues. In K. D. Valentine \& L. J. Jensen (Eds.), Examining the Evolution of Gaming and Its Impact on Social, Cultural, and Political Perspectives. (pp. 195-218). Hershey: IGI Global. Retrieved from https://www.igi-global.com/chapter/serious-games-teaching-values/157622

Golding, D. (2013). Videogames and politics: Why was Escape From Woomera so divisive? Retrieved 4 May 2015, from http://www.abc.net.au/arts/blog/Daniel-Golding/videogames-politics-EscapeFrom-Woomera-130901/

Green, S. C. (2014). The Perceptual and Cognitive Effects of Action Experience. In F. C. Blumberg (Ed.), Learning by Playing: Video Gaming in Education (pp. 29-41). New York: OUP.

Half The Sky Movement Game: From oppression to opportunity - raising awareness and funding. (2015). Retrieved 10 July 2015, from http://designtoimprovelife.dk/half-the-sky-movement-game-fromoppression-to-opportunity-raising-awareness-and-funding/

Holpuch, A. (2013). Half the Sky Facebook game launches with women's empowerment at core. Retrieved 10 July 2015, from http://www.theguardian.com/technology/2013/mar/04/facebookgame-half-the-sky

Klopfer, E., Osterweil, S., \& Salen, K. (2009). Moving learning games forward. Cambridge, MA: The Education Arcade.

Lazzaro. (2015). The 4 Keys 2 Fun | Nicole Lazzaro's Blog. Retrieved 7 July 2015, from http://www. nicolelazzaro.com/the4-keys-to-fun/

Maurin, F. (2017, December 8). The emotional rollercoaster of making a video game. Retrieved 9 February 2018, from https://medium.com/@ThePixelHunt/the-emotional-rollercoaster-of-making-avideo-game-e3983ab02495 
Mitgutsch, K. \& Alvarado, N. (2012). Purposeful by design?: a serious game design assessment framework. In Proceedings of the International Conference on the foundations of digital games (pp. 121-128). ACM.

OHCHR | Human Rights Education and Training. (n.d.). Retrieved 6 February 2018, from http://www. ohchr.org/EN/Issues/Education/Training/Pages/HREducationTraininglndex.aspx

Parkin, S. (2006). Darfur is Dying. When videogames discovered ethics. Retrieved 10 July 2015, from http://www.eurogamer.net/articles/i_darfurisdying_pc

Poremba, C. (2013). Performative Inquiry and the Sublime in Escape from Woomera. Games and Culture, 8(5), 354-367. https://doi.org/10.1177/1555412013493134

Sicart, M. (2008). Game Studies - Defining Game Mechanics. Retrieved 12 February 2018, from http:// gamestudies.org/0802/articles/sicart

Stokes, B., Seggerman, S. \& Rejeski, D. (2011). For a Better World: Digital Games and the Social Change Sector. Retrieved 7 July 2015, from http://www.gamesforchange.org/g4cwp/wp-content/ uploads/2011/06/g4cwhitepaper.pdf

Swain, C. (2007). Designing Games to Effect Social Change. Retrieved 18 September 2015, from http:// www.digra.org/wp-content/uploads/digital-library/07311.09363.pdf

Totals | Freerice.com. (2015). Retrieved 10 July 2015, from http://freerice.com/frmisc/totals

United Nations. (2014). Plan of Action for the third phase (2015-2019) of the World Programme for Human Rights Education. Retrieved from https://documents-dds-ny.un.org/doc/UNDOC/GEN/ G14/099/55/PDF/G1409955.pdf?OpenElement

Wolonick, J. (2013). The Half The Sky Movement: Is A Facebook Game The Next Step Toward Global Social Justice? Retrieved 10 July 2015, from http://www.minyanville.com/sectors/media/articles/ Half-the-Sky-Movement253A-Improving-Foreign/3/12/2013/id/48644?refresh=1

Sonja Gabriel

$\mathrm{KPH}$ Wien/Krems

Email: sonja.gabriel@kphvie.ac.at ORCID: https://orcid.org/0000-0002-0379-952X

Correspondência: Sonja Gabriel Mayerweckstrasse 1 1210 Vienna, Austria

Data de submissão: Junho 2018

Data de avaliação: Julho 2018

Data de publicação: Setembro 2018 